\title{
DEFINITIONS OF VIOLENCE AGAINST WIVES AMONG INDONESIAN SOCIAL WORK COLLEGE STUDENTS
}

\author{
Binahayati Rusyidi \\ Social Welfare Department, Universitas Padjadjaran, Bandung \\ Email: binahayati@unpad.ac.id \\ Kusuma Wulandari \\ Social Welfare Department, Universitas Jember \\ Asep Jahidin \\ Social Welfare Department, Universitas Islam Negeri Yogyakarta \\ Rudi S. Darwis \\ Social Welfare Department, Universitas Padjadjaran, Bandung
}

\begin{abstract}
Violence against wives is the most common form of violence against women reported in Indonesia. Understanding the definition of violence against wives is one of first steps to address the problem given that recognition about what constitutes violent behaviors has an influence on how society responds to victims and perpetrators. The study described and examined factors associated with the attitudes of Muslim undergraduate social welfare students toward definitions of violence against wives using socio-demographic and socio-cultural perspectives. Samples were selected non-randomly using convenience sampling techniques. Data were collected through a self-administered survey taken by 275 students in the social welfare department of two separate universities located in the provinces of Yogyakarta and East Java late 2016. Data was analyzed using hierarchical regressions techniques. The study found that students generally reported stronger agreement to viewing physical violence as a form of violence against wives. On the contrary, they were less likely to view non-physical violence as violent behavior. Gender, attitudes toward gender roles, and type of university were found to be associated with attitudes toward the definition of violence against wives. Implications from the findings were discussed, taking into account the roles of educational institutions in shaping the students' attitudes.
\end{abstract}

Keywords: Attitudes, college students, definitions violence against wives, socio-cultural factors, socio-demographic factors.

\section{Introduction}

Violence against wives is one of the most common forms of intimate partner violence against women that occurs in all settings and among all socioeconomic, religious and cultural groups (World Health Organization, 2016). Violence against wives is viewed as any behavior perpetrated by the husbands against the wives that causes physical, psychological or sexual harm to wives. This can take form as physical, sexual, psychological, and economic violence. Each type of violence may be performed specifically or together at the same time. Physical violence covers a range of acts that use physical force to inflict injuries on or even cause the death of victims such as the use of weapons, slapping, hitting, kicking, chocking, and so on. Sexual violence includes forced sexual intercourse and different forms of sexual coercion. 
Psychological violence is the intentional use of verbal and nonverbal messages and communication to cause mental or emotional harm. Some examples of psychological violence include constant humiliation or threats of harm and other various controlling behaviors such as restricting access to financial or social resources, monitoring of movement, and so on (Garcia-Moreno, Jansen, Ellsberg, Heise and Watts, 2006; Ellsberg, Jansen, Heise, Watts, and GarciaMoreno, 2008; World Health Organization, 2012). Economic abuse refers to deliberate control by the perpetrator over family finances and resources in a way that may prevent women from seeking financial independence; or economic deprivation where the husband refuses to contribute financially or denies to provide food and basic needs for family members (Fawole, 2008).

The World Health Organization (2012) acknowledged intimate partner violence, including violence against wives, as a global phenomenon and called for actions by governments and society at large to prevent and eliminate it. In Indonesia, various efforts have been implemented to prevent and address the problem, including law reforms, campaigns, education, as well as the provision of services for victims and perpetrators. Nevertheless, violence against wives has been continuously ranked as the most common form of violence among all reported cases of violence against women in the country. Physical violence is the most common form of violence towards wives by husbands, followed by psychological and economic violence (Komnas Perempuan, 2017).

Studies have documented significant negative effects of violence among victims, families and societies. Understanding attitudes on what constitutes abusive behavior is one of the first steps needed to identify and address the problem of violence against wives. Various studies found that attitudes toward violence against women are closely related to the practice of violence against women. Attitudes toward violence against women also influence responses to victims, including of social institutions such as social service providers and criminal justice systems. The victims' failure to recognize violent acts as violence can prohibit them from identifying as victimized and requiring help (Petersen, Moracco, Goldstein, and Clark, 2005). Similarly, the inability of health, social and criminal justice service providers as well as communities at large to understand violent acts may prevent them from providing effective services to help victims (Flood and Pease, 2009).

This study examined undergraduate social work students' definitions or recognitions of the various types of acts done by husbands as violence against wives and the factors associated with the definitions from sociodemographic and socio-cultural perspectives.

The significance of this study is founded on three main reasons. Firstly, those who graduate with an undergraduate-level social welfare education are likely to become social workers with the responsibility to perform their professional roles. Social workers are called upon to address the issue of violence against women as therapy providers, community educators, policy makers or researchers. Obtaining information on social welfare students' recognition of definitions and factors associated with forms of violence against wives can inform educational institutions to address any gaps in education process. Secondly, studies on college student' attitudes toward definitions of violence against women have been carried out in many countries, especially in non-Muslim society such as United States, China and Israel (Nabors, Dietz, \& Jasinski, 2006; HajYahia \& Schiff, 2007; Lin, Sun, Wu \& Liu, 2016; Jiao, Sun, Farmer \& Lin, 2016; Baldwin-White \& Elias-Lambert, 2016). The literature review found no similar studies done in Indonesia or specifically targeting social work students.

This study is important in both its ability to address gaps in knowledge of college students' definitions of violence against wives in different regional and cultural contexts. 
Lastly, previous studies on definitions of violence against women tended to measure limited forms of violence, focusing on sexual and physical forms and thus neglecting other important types of violence such as emotional and economic violencewhich will be addressed by this study (Lee, Busch-Armendaris, Kim and Lim, 2007; Lee, Kim and Lim; 2010).

\section{Method}

The samples of study were undergraduate students of the social welfare department at two state universities in the provinces of Yogyakarta and East Java. The former is an Islamic state university administered under the Ministry of Religion and the latter is a state university administered under the Ministry of Research and Technology and Higher Education. Samples were selected non-randomly using convenience sampling techniques. Coordinating with the lecturers, the researchers approached students in their classes and offered them to participate in the study. Students who agreed to take part in the study gave consent and completed the questionnaire in class. Data were collected in late 2016.

The dependent variable of the study was the participants' definition of violence against wives. Definition of Violence Against Wives Scale was used to measure the participants' perceptions in categorizing certain physical, psychological, economic and sexual violence and social control targeted at the wife by the husband as violence against wives. The scale consisted of 13 items with five-point Likert scale responses where one (1) was "strongly disagree", three (3) was "neutral", and five (5) was "strongly agree". The highest possible score is 65 and the lowest possible score is 13. Higher scores signal more agreement with viewing the given behaviors as a form of violence against wives whereas lower scores indicate less agreement with viewing the given behaviors violence against wives. The Cronbach's alpha score of the scale in this study was 0.80 , indicating a good internal consistency.

The independent variables in this study included four socio-demographic variables, namely gender, age, highest education obtained by respondent's mother, and highest education obtained by respondent's father. Three socio-cultural variables were investigated, namely university, attitudes toward gender roles, and level of religiosity. Ethnicity and religion, although considered as socio-cultural variables, were not examined in the study because more than $90 \%$ of participants reported that they were Javanese or Moslem.

Instruments used to measure socio-cultural factors included two existing standardized scales: Attitudes Toward Women Scaleshort version (Spence, Helmreich, 1978) and Religiosity Scale (Haj-Yahia, 1998). The short version of the Attitudes Toward Women Scale (ATWS) assesses individual's attitudes toward gender roles. The scale consists of 15 statements concerning the rights, roles, and obligations that women should have in modern society measured using a four point Likert scale where $1=$ "strongly disagree", 2 = "mildly disagree", 3 = "mildly agree", and 4 = "strongly agree". The ATWS is scored so that a high score reflects more feminist, egalitarian attitudes and a low score reflects more conservative, traditional gender attitudes (Helmreich, Spence, \& Gibson, 1982). ATWS had been validated in numerous studies, including ones in Indonesia; with good internal consistency (Rusyidi, 2011) The Cronbach's alpha for the Scale in this study was 0.73.

The Haj-Yahia Religiosity Scale was utilized to measure the participants' level of religiosity. The scale consists of three items to measure the religiosity of participants. Responses to the items are based on a 6point Likert-type scale in which $1=$ "not at all" and $6=$ "very much". A higher score indicates a higher level of religiosity and a lower score indicates a lower level of religiosity. The scale has been used in several studies with populations with varied religious affiliations in Middle Eastern countries (Haj-Yahia, 1998) and Indonesia (Rusyidi, 2011). In this study, the Cronbach's alpha of the scale was 0.74 .

A series of descriptive statistical analyses were performed to describe respondents' socio-demographic characteristics, attitudes 
toward gender roles, level of religiosity, and perceptions surrounding definitions of abuse towards wives. Several variables were recoded. Gender was recoded as categorical variable $(1=$ female, $0=$ male $)$ and so was university of attendance ( $1=$ university in Yogyakarta, 0 = university in East Java). Other independent variables were regarded as continuous variables. Hierarchical multiple regressions were performed to test the hypothesis. Hierarchical multiple regression enables the researcher to investigate how much $\mathrm{R}^{2}$ (variability explained by the regression model) increases by adding other variables in each model (equation). It also informs how much the effect of one block of independent variable changes when another block of independent variable is added into the model. Beta score (standardized coefficient) is used to indicate the direction and size of the effect of the predictor variable on outcome variables (Tabachnick \& Fidell, 2007).

Several pre-regression analyses were performed prior to multiple regressions. The check of normality in this study suggested the absence of non-normality. The tests for linearity in this study indicated that nonlinearity was not a problem. Additionally, the assumption of homoscedasticity was not violated and no high multiple co-linearity was found in this study (Tabachnick \& Fidell, 2007).

\section{Result and Discussion}

\subsection{Result}

Table 1 below depicts the general profile of informants. A total of 275 undergraduate social welfare students completed the survey. About 56 percent (156) of the students were from the Islamic state university in Yogyakarta and the rest (43 percent or 119 students) came from the state university in a city of East Java. The participants' age ranged from 16 to 24 years with a mean age of 19.6 years. More than $56 \%$ of students were females and $43 \%$ were males. The participants were studying at various points between their first to fourth year but 90 percent of them were students in one of the first three years.
The level of the students' father's highest education was quite diverse but the majority of the students' fathers had graduated from senior high school or received a higher level of education. More than half of the students' fathers graduated from high school, a fifth graduated from primary schools, and $15 \%$ had an undergraduate degree. The profile of the students' mother's highest education varied as well, but was relatively lower compared to the fathers' education. Forty five percent of students' mothers graduated from senior high school and 23\% completed primary school. Almost 14\% of the students' mothers graduated from either middle school or an undergraduate institution.

\section{Table 1. Frequency of students' based on their socio-demographic profile $(N=275)$}

\begin{tabular}{|c|c|c|}
\hline Variables & $\begin{array}{l}\text { Frequency } \\
(\mathrm{N})\end{array}$ & $\begin{array}{l}\text { Percent } \\
\text { age }(\%)\end{array}$ \\
\hline \multicolumn{3}{|l|}{ Year of study } \\
\hline Before 2014 & 28 & 10.2 \\
\hline 2014 & 85 & 31.3 \\
\hline 2015 & 81 & 29.8 \\
\hline 2016 & 78 & 28.7 \\
\hline \multicolumn{3}{|l|}{$\begin{array}{l}\text { Father's highest } \\
\text { education }\end{array}$} \\
\hline Primary education & 54 & 19.9 \\
\hline Junior secondary & 25 & 9.2 \\
\hline Senior secondary & 137 & 50.6 \\
\hline Diploma & 9 & 3.3 \\
\hline $\begin{array}{l}\text { Under } \\
\text { graduate }\end{array}$ & 40 & 14.8 \\
\hline Postgraduate Master & 4 & 1.5 \\
\hline Postgraduate Doctor & 2 & .7 \\
\hline \multicolumn{3}{|l|}{$\begin{array}{l}\text { Mother's highest } \\
\text { education }\end{array}$} \\
\hline Primary education & 61 & 22.7 \\
\hline Junior secondary & 37 & 13.8 \\
\hline Senior secondary & 121 & 45 \\
\hline Diploma & 9 & 3.3 \\
\hline Undergraduate & 37 & 13.8 \\
\hline Postgraduate Master & 3 & 1.1 \\
\hline Postgraduate Doctor & 1 & .4 \\
\hline
\end{tabular}

Table 2 (shown below) reports the frequency of students' definitions of violence against wives. Overall, the students indicated greater agreement to define physical violence than non-physical violence as abusive behavior against wives. They were less likely to define emotional abuse and controlling behavior as violent acts. For example, almost $87 \%$ students agreed and strongly agreed that threatening to hurt wives with sharp objects is violent behavior $(M=4.33)$. Eighty five percent, 83 percent, and 67 
percent respectively strongly agreed or agreed to view that slapping wives $(\mathrm{M}=$ 4.36) and throwing hard objects at wives $(M=4.58)$ were violent acts. Furthermore, almost $70 \%$ of students agreed that forcing to have sex with wives as a form of violent behavior $(\mathrm{M}=3.88)$.

In contrast, a much smaller percentage of participants acknowledged their agreement that other form of behaviors, including controlling acts, as violent behavior. For example, less than $10 \%$ and $15 \%$ participants acknowledged that demanding to know where one's wife is and who she interacts with at all times $(\mathrm{M}=2.18)$ and a husband's controlling of family assets as forms of abusive behavior ( $M=2.60)$, respectively. Only slightly more than $15 \%$ and $25 \%$ of students in this study reported their agreement with viewing the prohibition of wives from working or continuing their education without valid reason $(\mathrm{M}=2.61)$ and limiting wives' opportunities to make decisions $(\mathrm{M}=2.82)$ as abusive acts, respectively. Furthermore, less than onethird of participants reported viewing forcing wives into having sex as violent behavior.

Table 2. Frequency of participants Definitions of Violence Against Wives

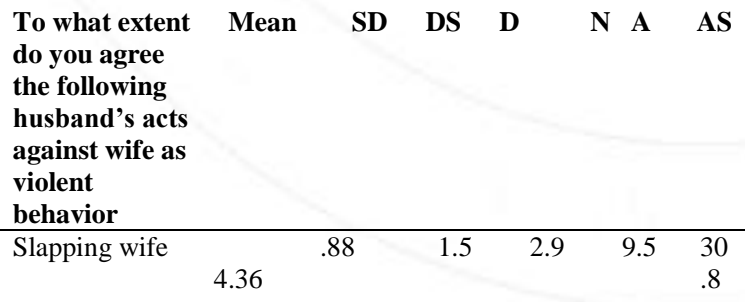

\begin{tabular}{lllllll}
\hline $\begin{array}{l}\text { Threating to } \\
\text { kill wife with } \\
\text { sharp objects }\end{array}$ & 4.33 & .94 & 2.6 & 4.0 & 5.9 & 33 \\
& & & & & & .3 \\
\end{tabular}

\begin{tabular}{|c|c|c|c|c|c|c|c|}
\hline $\begin{array}{l}\text { threating to } \\
\text { divorce wife }\end{array}$ & 3.25 & & & & & .8 & $\begin{array}{l}4 \\
5 \\
3\end{array}$ \\
\hline $\begin{array}{l}\text { Verbal abuse } \\
\text { to insult wife }\end{array}$ & 3.67 & 1.00 & 2.9 & 10.6 & 23.1 & $\begin{array}{l}43 \\
.6\end{array}$ & $\begin{array}{l}1 \\
9\end{array}$ \\
\hline $\begin{array}{l}\text { Throwing } \\
\text { hard objects at } \\
\text { wife (i.e. } \\
\text { astray, glass } \\
\text { plates) }\end{array}$ & 4.58 & .80 & 1.8 & 1.8 & 37 & $\begin{array}{l}22 \\
.3\end{array}$ & $\begin{array}{l}8 \\
7 \\
0 \\
. \\
3\end{array}$ \\
\hline $\begin{array}{l}\text { Refusing to } \\
\text { provide for } \\
\text { wife needs }\end{array}$ & 3.74 & 1.13 & 5.1 & 11.0 & 16.9 & $\begin{array}{l}38 \\
.6\end{array}$ & $\begin{array}{l}2 \\
8 \\
. \\
3\end{array}$ \\
\hline $\begin{array}{l}\text { Limiting wife } \\
\text { socialization } \\
\text { with her } \\
\text { families and } \\
\text { friends }\end{array}$ & 3.04 & 1.10 & 6.6 & 28.6 & 30.0 & $\begin{array}{l}23 \\
.8\end{array}$ & $\begin{array}{l}1 \\
1 \\
0\end{array}$ \\
\hline $\begin{array}{l}\text { Forcing wife } \\
\text { to have sexual } \\
\text { intercourse }\end{array}$ & 2.88 & 1.26 & 16.5 & 23.1 & 28.6 & $\begin{array}{l}19 \\
.4\end{array}$ & $\begin{array}{l}1 \\
2 \\
5 \\
5\end{array}$ \\
\hline $\begin{array}{l}\text { Prohibiting } \\
\text { wife to work } \\
\text { or continue } \\
\text { education } \\
\text { without valid } \\
\text { reasons }\end{array}$ & 2.61 & .99 & 12.1 & 35.9 & 35.5 & $\begin{array}{l}12 \\
.1\end{array}$ & $\begin{array}{l}4 \\
4\end{array}$ \\
\hline $\begin{array}{l}\text { Controlling } \\
\text { family assets }\end{array}$ & 2.60 & .97 & 12.1 & 34.6 & 37.9 & $\begin{array}{l}11 \\
.8\end{array}$ & 3 \\
\hline $\begin{array}{l}\text { Demanding to } \\
\text { know where } \\
\text { one's wife is } \\
\text { and who she } \\
\text { interacts with } \\
\text { at all times }\end{array}$ & 2.18 & .92 & 22.3 & 47.6 & 21.2 & $\begin{array}{l}7 . \\
0\end{array}$ & $\begin{array}{l}1 \\
8\end{array}$ \\
\hline $\begin{array}{l}\text { Restricting } \\
\text { wife to make } \\
\text { decision }\end{array}$ & 2.82 & 1.00 & 6.2 & 38.1 & 29.3 & $\begin{array}{l}20 \\
.5\end{array}$ & $\begin{array}{l}5 \\
9 \\
9\end{array}$ \\
\hline $\begin{array}{l}\text { Forcing wife } \\
\text { to have sex in } \\
\text { an disgrace or } \\
\text { unacceptable } \\
\text { way }\end{array}$ & 3.88 & 1.04 & 2.6 & 9.2 & 18.7 & $\begin{array}{l}37 \\
.4\end{array}$ & $\begin{array}{l}3 \\
2 \\
2\end{array}$ \\
\hline
\end{tabular}

$\mathrm{SD}=$ Standard Deviation; $\mathrm{DS}=$ Disagree Strongly; $\mathrm{D}=$ Disagree; $\mathrm{N}=$ Neutral; $\mathrm{A}=$ Agree; $\mathrm{AS}=$ Agree Strongly

Table 3 (shown below) shows the results from multivariate hierarchical regression analysis. Model 1 included only sociogemographic variables. Sex was a significant predictor, with female more Bkely to define certain behaviors as violence against wives than male students. All sociodemographics variables explained $26.7 \%$ of the variation in violence against wives \&efinitions. In model 2, three variables were \begin{tabular}{lllllll}
\hline Often & 1.11 & 7.0 & 17.9 & 33.0 & 27 & ddded and achieved statistical significance
\end{tabular} 
with the attitudes toward gender roles and university of origin as significant predictors. Students who agreed with gender equality were more likely to define certain behaviors as violence against wives than students who were less agreed with gender equality. Students from the university in Yogyakarta were more likely than their East Java's counterpart to define certain acts as abusive. All explanatory variables accounted for almost $33 \%$ of the variation in violence against wives definition. Finally, in the full model (model 3), both socio-demographics and socio-cultural predictors were added. The model also achieved statistical significant.
Three predictors remained significant with attitudes toward gender roles as the strongest predictor, followed by the type of university and sex. All socio-demographic and sociocultural variables accounted for $37.6 \%$ of the variation in the definitions of violence against wives.

Table 3. Regression Definitions of Violence Against Wives on Socio-Demographic and SocioCultural Related Variables: Parameter Estimates From a Hierarchical Analysis $(N=275)$

\begin{tabular}{|c|c|c|c|c|c|c|}
\hline \multirow{2}{*}{$\begin{array}{l}\text { Predictor } \\
\text { Variables }\end{array}$} & \multicolumn{2}{|c|}{ Model 1} & \multicolumn{2}{|c|}{ Model 2} & \multicolumn{2}{|c|}{ Model 3} \\
\hline & Beta & SE & Beta & SE & Beta & SE \\
\hline \multicolumn{7}{|l|}{ Socio-demographics } \\
\hline $\begin{array}{l}\text { Gender } \\
(1=\text { Female })\end{array}$ & $.248 * * *$ & .823 & & & $.153 * *$ & .876 \\
\hline Age & .077 & .310 & & & .098 & .317 \\
\hline Father's education & .057 & .388 & & & -.041 & .379 \\
\hline Mother's education & .090 & .381 & & & .085 & .371 \\
\hline Socio-cultural & & & & & & \\
\hline $\begin{array}{l}\text { Attitudes about } \\
\text { gender roles }\end{array}$ & & & $.294 * * *$ & .059 & $.228 * * *$ & .063 \\
\hline Religiosity & & & .003 & .141 & .003 & .144 \\
\hline $\begin{array}{l}\text { University } \\
(1=\text { Yogyakarta })\end{array}$ & & & $.180 * *$ & .785 & $.191 * *$ & .814 \\
\hline Model $\mathrm{R}^{2}$ & .267 & & .328 & & .376 & \\
\hline
\end{tabular}

\subsection{Discussions}

There are several major findings from the study that corroborate findings from the previous studies. First, there is stronger agreement in defining violence against wives as physical violence. Participants agreed less to classify non-physical violence as violence against wives. This tendency has been reported in past studies done in both Asian or Western societies. For example, a study conducted by Nabors et al. (2006) among college students in the United States revealed that participants reported stronger agreement to view physical aggression as a form of abusive behavior than non-physical aggressions. Ninety seven percent of the participants agreed that punching one's wife as abusive behavior but only less than half and less than $25 \%$ of students agreed that controlling behavior such as stalking and verbal abuse, respectively, were forms of abusive behavior against wives/partners. Similar patterns were also found in a study among Chinese individuals in Hong Kong (Tang, Wong, Cheung and Lee, 2000).

The tendency of not considering nonphysical violence a form of violence against wives may be related to perceptions that non-physical violence involves less direct or immediate physical injuries and thus is perceived as less violent behavior. In reality, studies have found that victims experience 
non-physical forms of violence more often than physical violence and that some forms of non-physical violence are clear risk factors for physical violence. In addition, studies have confirmed that the impacts of non-physical intimate partner violence are as threatening and/or damaging as physical violence (Antai, 2011). Neglecting nonphysically violent acts in defining violence against wives does not only undermine victims' experiences but also ignores the potential negative impacts they may cause.

Although the participants were generally less likely to define non-physical violence as a form of abusive behavior than physical violence, there is some variance in agreement with viewing different types of non-physical violence as abusive. Participants were more likely to agree that insulting wives' feelings verbally, forcing wives to have intercourse, and neglecting to provide for wives' needs are forms of violence against wives more than other nonphysical violent acts. Such understanding seems to be influenced by the context of culture and religion. As a predominantly Moslem country, Islam has a strong influence upon society's norms and belief. For example, in Islam, verbal abuse, either in marital or social relations, is prohibited. Islam also regulates that sexual relations between a husband and wife should be done in a respectful and graceful way. Additionally, Islam emphasizes the husband's responsibility to fulfill both his wife's material and immaterial needs and how negligence of such provisions is considered a violation of wife's rights.

Interestingly, forcing wives to have intercourse was more likely to not be considered as violent behavior, as were actions like strict control of one's wife's mobility and decision making. It is possible that many participants believed that as the head of family, a husband has more say than his wife in making decisions and has the right to monitor his wife's activities. Furthermore, many participants might have not considered forced sex in marriage as violence because they perceive a husband's access to sex as not needing his wife's consent. Existing norms send strong messages that having sex with one's husband is a wife's obligation, thus discouraging refusal (Hakimi, Hayati, Marlinawati, and Ellsberg, 2001; Rusyidi, 2011).

The study also validated the effect of gender on the definitions of violence against wives reported in previous cross-culture research in which female participants acknowledged wider ranges of behaviors as violence against wives than their male counterparts (Nayak, Bryne, Martin, and Abraham, 2003; Nabors et al., 2006; Lin et al., 2016;). This may be attributed to female participants' heightened awareness of wives being more likely to be victims of intimate partner violence than husbands, thus rendering them more sensitive in considering any type of violent act targeting women as violence.

The association between attitudes toward gender roles and definitions of violence against wives found in this study is consistent with the findings from other studies including among college students in the United States (Nabors \& Jasinski, 2009); and China, Hong Kong and Taiwan (Jiao et al., 2016). Individuals who have lower endorsement of gender equality are more likely to have narrower definitions of violent behavior than those who agree with gender equality. Those who adhere to traditional gender role beliefs are more likely to subscribe to notions that structures of families as well as social structures should be based on gender division. Traditionally, in Indonesia, men are given more power to assume leadership and control in the family and society while women are to complement men and be submissive. Feminist theorists have argued that this power difference sets the stage for abuse of wives. Consequently, traditional Indonesians may be less likely to define various forms of abuse as violence against wives.

The study also found interesting evidence on the type of university being associated with how students defined violence against women. Students from the religiously affiliated university in Yogyakarta reported broader definitions of violence against women than students from the unaffiliated university in East Java. Further analysis should be done to examine this finding, but 
existing observations indicate that the students in Yogyakarta are more exposed to thoughts on critical human rights and gender equality through classes and non-curricular activities than their counterparts in East Java. Such exposure may make students in Yogyakarta more informed about violence against wives and posses more sensitive attitudes toward it.

\section{Conclusions}

The finding highlights that improving social work students' understanding of what constitutes as violent behavior against wives is necessary. Social work students' broader understanding of violence against wives will help them view the seriousness of the issue. This in turn will encourage students to equip themselves with competencies to educate the public, mobilize greater resources to address the issue, and to advocate for more comprehensive social policies to eliminate the problem.

Efforts to improve the students' understanding about definitions of violence against wives should be especially emphasized among male students given that their understanding of the issue is significantly narrower than their female counterparts. Furthermore, since attitudes toward gender roles was found as the strongest predictor in this study, attempts to increase students' understanding of the definition of violence against wives should be carried out together with measures to improve students' attitudes toward gender roles. This may be done through the introduction of relevant classes or teaching materials that cover topics such as human rights and gender equality. The teachings may also include the protections of wives or women's rights according to Islamic perspectives. Additionally, students should be introduced and encouraged to become involved in the implementation of field practices in organizations working to protect and empower women.

The findings from the study indicate that the recognition of the definitions of violence against wives was not even across universities with one university performing much better than the other. This calls for action from the Indonesian Association of Social Work Education in reviewing the standard of social work curriculum and its implementation. The integration of gender and social justice issues into the national curriculum appears to be necessary considering their pressing urgency.

Future studies are needed to validate the findings in a bigger population, including studies that cover social welfare students from universities outside Java and examine non-Muslim students. The influences of some socio-demographic and socio-cultural factors have been found to be significant, thus, future studies that examine other related factors would be important. Comparison studies between Indonesian students and students in other countries may be beneficial in informing us further of the impacts of cultural and socio-economic contexts upon students' definitions of violence against wives.

\section{References}

Antai, D. (2011). Controlling behavior, power relations within intimate relationships and intimate partner physical and sexual violence against women in Nigeria. BMC Public Health, 11, 511-522.

Baldwin-White, A. \& Elias-Lambert, N. (2016). Rape myth acceptance among social work students. Journal of Aggression, Maltreatment \& Trauma, 25 (7), 702-720.

Ellsberg M. C., Jansen H., Heise L., Watts C. H., Garcia-Moreno C. (2008). Intimate partner violence and women's physical and mental health in the WHO multi-country study on women's health and domestic violence: An observational study. The Lancet, 371, 1165-1172. doi:10.1016/s0140-6736(08)60522

Garcia-Moreno C., Jansen H., Ellsberg M., Heise L., Watts C. H. (2006). Prevalence of intimate partner violence: Findings from the WHO multi-country study on women's health and domestic violence. The Lancet, 368, 12601269

Fawole, O.I. (2008). Economic violence to women and girls. Is it receiving the 
necessary attention?. Trauma, Violence \& Abuse, 9 (3), 167-177.

Flood, M. \& Pease, B. (2009). Factors influencing attitudes to violence against women. Trauma, Violence \& Abuse, 10 (2), 125-142.

Goldblatt, H. (2009). Caring for abused women: impact on nurses' professionals and personal life experiences. Journal of Advanced Nursing 65 (81), 1645-1654.

Haj-Yahia, M.M. (1998). Beliefs about wife beating among Palestinian women: The Influence of their patriarchal ideology. Violence Against Women, 4, 533-558.

Haj-Yahia, M.M. \& Schiff, M. (2007). Definitions of and beliefs about wife abuse among undergraduate students of social work. International Journal of Offender Therapy \& Comparative Criminology, 51, 170-189.

Hakimi, M., Hayati, E.E., Marlinawati, V.U., and Ellsberg, M.C.. (2001). (Ed.). Silence for the sake of harmony: Domestic violence and women's health in Central Java, Indonesia. Yogyakarta, Indonesia: CHN-RL GMU.

Hayati, E.N., Hogberg, U., Hakimi, M., Ellsberg, M.C., \& Emmelin, M. (2011). Behind the silence of harmony: Risk factor for physical and sexual violence among women in rural Indonesia. BMC Women's Health, 11.

Helmreich, R. L., Spence, J. T., \& Gibson, R. H. (1982). Sex role attitudes 19721980. Personality and Social Psychology, 37, 1631-1644.

Jiao, Y., Sun, I.Y., Farmer, A.K., \& Lin, K. (2016). College students' definitions of intimate partner violence: A Comparative study of three Chinese societies. Journal of Interpersonal Violence, 31 (7), 1208-1229.

Kelly, J.B. (2008). Differentiation among types of intimate partner violence: Research update and interpretations for interventions. Family Court Review, 46 (3), 476-499.

Komnas Perempuan. (2013). Kekerasan Seksual. Downloaded from o 17 October 2016 from http://www.komnasperempuan.go.id/ wp-

content/uploads/2013/12/KekerasanSeksual-Kenali-dan-Tangani.pdf on 17 Oktober 2016.

Komnas Perempuan. Lembar Fakta Catatan Tahunan (Catahu) 2016 - 7 Maret 2016. Downloded on 20 October 2016 from http://www.komnasperempuan.go.id/1 embar-fakta-catatan-tahunan-catahu2016-7-maret-2016/

Lee, J., Busch-Armendaris, N.B., Kim, J.\& Lim, H. (2007). Attitudes toward date rape among university students in South Korea. Sex Roles, 57 (9), 641649.

Lee, J., Kim, J., \& Lim, H. (2010). Rape myth acceptance among Korean college students: The Roles of gender, attitudes toward women and sexual double standard. Journal of Interpersonal Violence, 25 (7), 12001223.

Lee, J., Lee, C., Lee, W. (2012). Attitudes toward women, rape myths, and rape perceptions among male police officers in South Korea. Psychology of Women Quarterly, 36(3), 365-376.

Lin, K., Sun, I.Y., Wu, Y. \& Liu, J. (2016). College students' attitudes toward intimate partner violence: A Comparative study of Chinese and the United States. Journal of Family Violence, 31: 179-189.

Nabors, E.L., Dietz, T.L., \& Jasinski, J. (2006). Domestic violence beliefs and perceptions among college students. Violence and Victims, 21 (6), 779-795.

Nayak, M., C. Byrne, M. Martin, and A. Abraham (2003) Attitudes towards violence against women: A crossnation study. Sex Roles, 49(7/8), pp. 333-342.

Petersen, R., Moracco, K.E., Goldstein, K.M., \& Clark, K.A. (2004). Moving beyond disclosure: women's perspectives on barriers and motivators to seeking assistance for intimate partner violence. Women Health, 40 (3), 63-76.

Rusyidi, B. (2011). Attitudes toward violence against wives in West Java, Indonesia. Unpublished Dissertation. School of Social Welfare, State 
University of New York: Albany, New York, USA.

Steinmetz, S., \& Haj-Yahia, M. M. (2006). Definitions of and beliefs about wife abuse among ultra-Orthodox Jewish men from Israel. Journal of Interpersonal Violence, 21, 525-554.

Tabachnick, B. G., \& Fidell, L. S. (2007). Using multivariate statistics. Boston: Pearson/Allyn \& Bacon.

Tang, C.S., Wong, D., Cheung, M.C., \& Lee, A. (2000). Exploring how Chinese define violence against women: A Focus group study in Hong Kong. Women's Studies International Forum, 23 (2), 197209.

Yllo, K. A., \& Straus, M. A. (1990). Patriarchy and violence against wives: The impact of structural and normative factors. In M. A. Straus \&R. J. Gelles (Eds.), Physical violence in American families: Risk factors and adaptations to violence in 8,145 families (pp. 383-399). New Brunswick, NJ: Transaction.

World Health Organization. (2012). Understanding and addressing violence against women. Downloaded on 20 October 2016 from

2016http://apps.who.int/iris/bitstream /10665/77432/1/WHO_RHR_12.36_ eng.pdf.

World Health Organization. 2016. Fact Sheets. Intimate partner and sexual violence against women. 